\title{
Oxygen Consumption, Diffusing Capacity and Blood Flow of the Synovial Membrane in Osteoarthritic Rabbit Knee Joints
}

\author{
By Ellıv Svalastoga and Thomas Kiar
}

Department of Small Anımal Diseases and Clınıcal Practıce, Royal Veterinary and Agricultural University, Copenhagen and Department of Orthopaedıc Surgery, Rigshospitalet, University of Copenhagen, Denmark.

\begin{abstract}
Svalastoga, E. and T. Kiær: Oxygen consumption, diffusing capacity and blood flow of the synovial membrane in osteoarthritic rabbit knee joints. Acta vet. scand. 1989, 30, 121-125. - In osteoarthritis the changes of the synovial membrane may seriously alter the oxygen transfer characteristics from the capillaries of the membrane to the synovial fluid and hence impede or deprive the joint cartilage of its sole source of oxygen.

In the present study we have estımated the blood flow $(\mathrm{Q})$, diffusing capacity $\left(\mathrm{DO}_{2}\right)$ and oxygen consumption $\left(\mathrm{VO}_{2}\right)$ of the synovial membrane in the chronic non effusive stage of experımental osteoarthritis.

In 14 osteoarthritıc knee joınts we found a statistically sıgnificant increase in oxygen consumption, compared to previously reported results from normal joints, whereas the diffusing capacity and the blood flow were unchanged. The implication of this is that the partial pressure difference required to overcome the increased oxygen consumption was increased with a factor 4.3 and that the oxygenation of the joint cartilage was reduced with approx. 30 Torr.
\end{abstract}

joint perfusion; mass spectrometry; blood flow.

\section{Introduction}

Osteoarthritis is a progressive disease involving all joint structures with increased morphological alterations as the disease progresses. In the synovial membrane the end stage of the disease is characterised by proliferation of the lining cells, villous hypertrophy, fibrosis and dilation of venules (Arnold $l$ et al 1980, Arnold \& Reimann 1979, Svalastoga \& Reımann 1985). Oxygenation of the joint cartilage depends on diffusion of oxygen across the synovial membrane and the synovial fluid.

These complex of structural changes in the synovial membrane might hamper the diffusive oxygen transfer from the capillaries of the synovial membrane to the synovial fluid.
A previous series of experiments have shown a considerably reduced oxygen transfer across the synovial membrane in the acute stage of experimental osteoarthritis (Svalastoga \& Grønlund 1985a, Svalastoga \& Grønlund 1985b).

The fact that the changes in the synovial membrane in chronic osteoarthritis coincide with a progressive deterioration of the joint cartilage warrants a study to elucidate whether synovial hypoxia is a persistent phenomenon in osteoarthritis. On this basis we have investigated the oxygen consumption, diffusing capacity and the blood flow in the synovial membrane in the osteoarthritic end stage. 


\section{Materials and methods}

Four months prior to the experiments 14 full grown New Zealand White rabbits underwent an instability operation a.m. Hult to induce unilateral osteoarthritis (Hult et al. 1970). This operation which was performed under intravenous anaesthesia (Pentobarbitone $5 \%$ ), includes resection of the medial collateral ligament, extirpation of the medial meniscus and transsection of both cruciate ligaments. At the 4 months stage of induced osteoarthritis the rabbits were utilized to study the oxygen consumption, diffusing capacity and the blood flow of the synovial membrane. A detailed description of the method is given elsewhere (Svalastoga et al 1989). The principle of the method is to perfuse the joint cavity with 2 saline solutions: one with high $\mathrm{O}_{2}$ and $\mathrm{N}_{2}$ partial pressures. Using a model of gas exchange between the joint cavity and the synovial membrane a set of 5 equations is derived expressing the relationship between oxygen and nitrogen flowing to and from the perfusate in the 2 situations and the diffusing capacity, metabolism and blood flow of the synovial membrane.

The experimental procedure and setup were very similar to that of a previous study ( $\mathrm{Sva}$ lastoga \& Grønlund 1985a). The rabbits were anaesthetized (pentobarbitone $5 \%$ ) and kept on spontaneous respiration throughout the study. The right carotid artery was cannulated to facilitate arterial blood sampling. The skin over the medial collateral and the infrapatellar ligament was anaesthetized $(0.5$ $\mathrm{ml}$ lidocaine $2 \%$ ). A 20 gauge cannula was inserted into the joint cavity via the infrapatellar ligament and a second cannula was inserted into medial femoro - tibial joint compartment through a medial horizontal approach. The joint was flushed with saline to remove synovia and debris. The rabbit was then moved to a heated box $37^{\circ} \mathrm{C}$ and the joint was perfused with an infusion pump (Harvard Apparatus, Millis, U.S.) at a rate of approximately $2.0 \mathrm{ml} / \mathrm{min}$, with the saline solution with either the low or the high partial pressures of nitrogen and oxygen first.

A blood gas catheter (Lundsgaard et al. 1980) connected to the mass spectrometer (Balzers, QMG, Balzers, Lichtenstein) enabled continuous and simultaneous measurement of the oxygen and the nitrogen partial pressures in the perfusate flowing from the joint cavity (Fig. 1). After attainment of steady $\mathrm{O}_{2}$ and $\mathrm{N}_{2}$ signals an arterial blood sample was taken to measure $\mathrm{PaO}_{2}$.

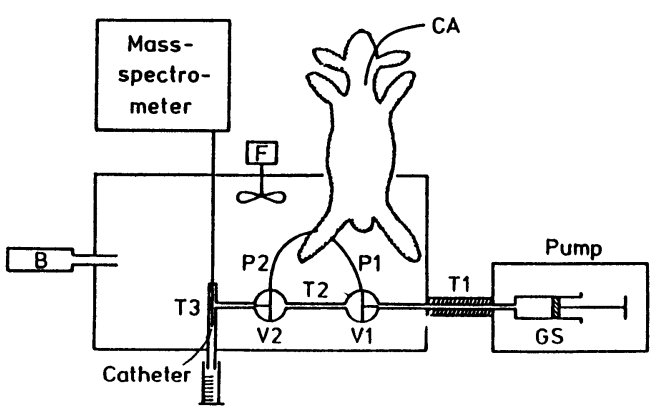

Figure 1. Experimental setup. For details see text and Svalastoga et al. 1989, Svalastoga \& Grønlund 1985.

\section{Results}

The results of the investigation are summarized in Table 1. The first 2 columns show the experiment number and the actual values of $\mathrm{PaO}_{2}$. Columns 3 to 5 represent the calculated oxygen consumption $\left(\mathrm{VO}_{2}\right)$, diffusing capacity $\left(\mathrm{DO}_{2}\right)$ and the blood flow (Q) in the synovial membrane of the osteoarthritic knee joints.

\section{Discussion}

The methodology and the assumptions on which the method used is based have been 

rabbit knee joints

Table 1. Calculated oxygen consumption, diffusing capacity and blood flow in osteoarthritic synovial membrane.

\begin{tabular}{rrrrr}
\hline No & $\begin{array}{c}\mathrm{PaO}_{2} \\
(\mathrm{Torr})\end{array}$ & $\begin{array}{c}\mathrm{VO}_{2} \\
(\mu \mathrm{l} / \mathrm{min})\end{array}$ & $\begin{array}{c}\mathrm{DO}_{2} \\
(\mu \mathrm{l} / \mathrm{m} \text { In/Torr })\end{array}$ & $\begin{array}{c}\text { Blood flow } \\
(\mathrm{ml} / \mathrm{m} \text { In })\end{array}$ \\
\hline 1.000 & 93.800 & 0.938 & 0.017 & 0.280 \\
2.000 & 73.200 & 1.317 & 0.029 & 0.360 \\
3.000 & 79.700 & 3.751 & 0.050 & 0.320 \\
4.000 & 117.900 & 1.800 & 0.022 & 0.440 \\
5.000 & 106.900 & 2.374 & 0.029 & 0.890 \\
6.000 & 81.800 & 1.223 & 0.028 & 0.750 \\
7.000 & 86.400 & 1.937 & 0.014 & 1.000 \\
8.000 & 93.800 & 0.938 & 0.017 & 0.280 \\
9.000 & 101.100 & 6.585 & 0.071 & 0.320 \\
10.000 & 87.700 & 1.106 & 0.025 & 0.480 \\
11.000 & 103.500 & 5.148 & 0.040 & 0.380 \\
12.000 & 65.800 & 1.333 & 0.020 & 0.290 \\
13.000 & 93.300 & 3.259 & 0.033 & 0.150 \\
14.000 & 52.000 & 1.540 & 0.041 & 0.450 \\
\hline MEAN & 88.350 & 2.375 & 0.031 & 0.456 \\
STD & 16.636 & 1.660 & 0.015 & 0.240 \\
SEM & 4.613 & 0.460 & 0.004 & 0.067 \\
\hline
\end{tabular}

Column 2) shows the measured values of the arterial oxygen tension $\left(\mathrm{PaO}_{2}\right)$, and column 3$), 4)$ and 5) the calculated oxygen consumption $\left(\mathrm{VO}_{2}\right)$, diffusing capacity $\left(\mathrm{DO}_{2}\right)$ and the blood flow $(\mathrm{Q})$.

described in detail elsewhere (Svalastoga et al 1989). The experimental model used in this study is based on a surgical technique producing medial instability of the knee (Hult et al 1970). The main advantage of this approach compared to studies on clinical cases of osteoarthritis is that it enables investigation of a uniform material at a well defined stage of the disease. A similar model has been widely used and the similarity to genuine osteoarthritis is well documented in osteoarthritic research (Bohr 1976, Christensen 1985, Christensen et al. 1982, Telhag \& Lindberg 1972).

When the results in this study are compared with the results obtained from normal rabbit knee joints (Svalastoga et al. 1989) a statistically significant increase in the oxygen con- sumption $\left(\mathrm{VO}_{2}\right)$ is seen $(\mathrm{p}<0.01$, Wilcoxon rank sum test), whereas there is no difference in diffusing capacity $\left(\mathrm{DO}_{2}\right)$ and blood flow (Q). This implies that there is an increase in the partial pressure difference across the synovial membrane required to overcome the cellular demands and hence a reduced oxygen transfer capacity from the synovial membrane to the cartilage. A previous analysis of the joint model (Svalastoga \& Grønlund 1985b, Svalastoga et al. 1989) has shown that the magnitude of the partial pressure difference across the synovial membrane $\left(\delta \mathrm{PO}_{2}\right)$ required to overcome the oxygen consumption can be estimated by insertion of the values of $\mathrm{VO}_{2}$ and $\mathrm{DO}_{2}$ in the equation:

$\delta \mathrm{PO}_{2}=\mathrm{VO}_{2} / 2 \mathrm{DO}_{2}$. 
Insertion of the present experimentally obtained values gives a mean $\delta \mathrm{PO}_{2}$ of 37.6 Torr, which is 4.3 times greater than the normal value of 8.7 Torr reported by Svalastoga et al. 1989 ( $\mathrm{p}<0.05$, Wilcoxon rank sum test). Hence the oxygenation of the joint cartilage is reduced with approx. 30 Torr. In vitro experiments have shown that cartilage cells exhibit both anaerobic and aerobic respiration (Lane et al. 1977, Stockwell \& Meachım 1979, Stockwell 1983). However, the cell function and synthesis is highly dependent upon the oxygen tension (Taylor 1981, Stockwell 1983). The interpretation of our results are that the cells of the joint cartilage are partially deprived their oxygen supply in late stage of osteoarthritis. In combination with other factors such as increased mechanical wear the metabolic demands of the cartilage cells may not be fullfilled (Richman et al. 1981).

\section{References}

Arnold I CC, Reimann I- The pathomechanism of human coxarthrosis. Acta orthop. scand. 1979, Suppl. 181.

Arnold CC, Reimann I, Bretlau $P$. The synovial membrane in human coxarthrosis. Clin. Orthop. 1980. 148, 213-220.

Bohr $H$ - Experimental osteoarthritis in the rabbit knee joint. Acta orthop. scand. 1976, 47, 558 -565 .

Christensen SB, Reimann I, Henriksen O, Arnold $\mathrm{CC}$. Experimental osteoarthritıs in rabbits. A study of $133 \mathrm{Xe}$ wash out rates from the synovial cavity. Acta orthop. scand. 1982, 53, 167-174.

Christensen SB. Osteoarthrosis. Acta orthop. scand. 1985, 56, suppl. 214.

Ehrlich MG, Mankın HJ, Jones H, Grossman $B A$, Crispin $C$, Ancona D: Biochemical confirmation of an experimental osteoarthritic model. J. Bone Jt. Surg. 1975, 57 A, 393-396.

Hult A, Lindberg L, Telhag $H$. Experimental osteoarthritis in rabbits. Acta orthop. scand. 1970, 41, 522-530.
Lane JM, Brighton CT, Menkowitz BJ Anaerobic and aerobic metabolism in articular cartılage. J. Rheumatol. 1977, 4, 344-342.

Lundsgaard JS, Jensen B, Grønlund $J$ Fast-responding flow-independent blood gas catheter for oxygen measurement. J. appl. Physiol. 1980, 48, 376-381.

Rıchman AI, Su EY, Ho G Reciprocal relationshıp of synovial fluid volume and oxygen tension. Arth. Rheum. 1981, 24, 701-705.

Stockwell A, Meachım $G$ The chondrocytes. In Adult Articular Cartilage. (Ed. MAR Freeman). Pitman, Kent 1979, pp. 69-145.

Stockwell RA Metabolısm of cartilage. In Cartilage. (Ed. BK Hall). Academic Press, New York 1983, pp. 253-280.

Svalastoga $E$, Grønlund $J$ Experimental osteoarthrosis in the rabbit. II. A new method to estimate the oxygen consumption and diffusion capacity in the synovial membrane of the knee. Acta vet. scand. 1985a, 26, 326-339.

Svalastoga $E$, Grønlund $J$ Experimental osteoarthritis in the rabbit. III. Acute osteoarthritis: subchondral $\mathrm{PO} 2$ and oxygen consumption and diffusion capacity in the synovial membrane. Acta vet. scand. 26, 1985b, 340-351.

Svalastoga E, Reimann I Experımental osteoarthritis in the rabbit. I. Histological changes in the synovial membrane. Acta vet. scand. 1985, 26, 313-325.

Svalastoga E, Klar T, Gronlund J Improved method to estımate oxygen consumption, diffusing capacity and blood flow of synovial membrane. Acta vet. scand. 1989, 30, 113-119.

Taylor T: Glucose metabolism and respiration. Clin. Rheum. Dis. 1981, 7, 167-175.

Telhag $H$, Lindberg $L$ A method for inducing osteoarthritic changes in rabbit knee. Clin. Orthop. 1972, 86, 214-223.

\section{Sammendrag}

Iltforbrug, diffusionskapacitet og blodgennemstromning $\imath$ synovialmembranen $\imath$ knaled hos kaniner med induceret osteoarthritis

I artrotiske led reduceres iltoverførslen fra synovialmembranens kapillærer til synovi, herved kan ledbrusken helt eller delvis berøves sin eneste oxygenkılde. 
I nærværende arbejde har v1 beregnet blod flow $(\mathrm{Q})$, diffusionskapacitet $\left(\mathrm{DO}_{2}\right)$ og metabolisme $\left(\mathrm{VO}_{2}\right)$ i 14 knæled i det kroniske stadie af experimentel artrose. $V_{1}$ fandt, sammenlignet med undersøgelse af normale led, en statıstısk sıgnifikant øget metabolisme, hvorimod de øvrige parametre var uforandrede. Dette medførte, at den partialtryksdifferens, som er nødvendig for at overkomme den øgede metabolisme, stiger med en faktor $4.3 \mathrm{og}$ at 1 ltforsyningen til ledbrusken reduceres med 30 Torr.

(Recelved March 22, 1988, accepted June 29, 1988)

Reprints may be requested from: Ellıv Svalastoga, Department of Small Anımal Diseases and Clınıcal Practıce, The Royal Veterinary and Agrıcultural University, Copenhagen, Bülowsvej 13, DK-1870 Frederiksberg C, Denmark. 
